\title{
THE IMPACT OF FEE INCOME SHARE ON EU BANKS' PERFORMANCE AND ITS IMPLICATIONS FOR DRIVERS OF BANKS' BUSINESS MODEL CHANGES*
}

\author{
Karolína Vozkováa
}

\begin{abstract}
This paper contributes to the current literature dealing with drivers of bank business model changes. We analyse the relationship between fee and commission income share and banks' performance in terms of profitability, risk and risk-adjusted profitability in the European Union. We applied the System Generalized Method of Moments to a unique data set of 329 EU banks in the period 2005-2014, which resulted in three key findings. First, we did not find any diversification benefits by increasing the fee income share. Therefore, we can conclude that the increase in fee income share observed in recent years in EU banks was driven mainly by external factors, such as increased competition, rather than by internal reasons. Second, higher reliance on equity financing and better quality of provided loans enhance banks' performance. Third, bank business strategies and macroeconomic factors are crucial determinants of banks' performance.
\end{abstract}

Keywords: Bank, EU, fee and commission income, profitability, risk

JEL Classification: C23, G21, L25

\section{Introduction}

An expansion of bank activities into non-traditional fee and commission-bearing services can be observed over the last few decades (Brighi and Venturelli, 2016). ${ }^{1}$ Banks are becoming more universal by combining traditional and non-traditional activities. Between 1989 and 1998, the non-interest income (NII) of EU banks increased from $26 \%$ to $41 \%$ of their total income (Lepetit et al., 2005). The most pronounced part of NII is net fee and commission income

a Charles University in Prague, Institute of Economic Studies, Prague, Czech Republic Email: vozkova.karol@gmail.com

* $\quad$ Financial support from the Grant Agency of Charles University (No. GAUK 488317) and the Czech Granting Agency (No. GACR 18-05244S) is gratefully acknowledged.

1 Traditional activities include deposit taking and loan providing. Non-traditional activities are, for example, retail brokerage, insurance sales and securities issuance. 
(NFCI), which accounted for almost $28 \%$ on average of the total income among EU banks in 2015 (ECB, 2016). Academicians, as well as bank managers, are mainly concerned with the impact of NII on the risk-return tradeoff. The theory of finance suggests that expanding into non-traditional activities should decrease the banks' risk level via diversification because fee income, trading income and other NII are not perfectly correlated with interest income (DeYoung and Roland, 2001; Smith et al., 2003). Moreover, diversification should also lead to higher risk-adjusted profits and higher efficiency due to economies of scope (Klein and Seidenberg, 1998; Elsas et al., 2010). However, the empirical evidence is mixed.

Some authors, such as Stiroh (2004), DeYoung and Rice (2004) and Stiroh and Rumble (2006), find that diversification benefits are more than offset by increased exposure to potentially riskier fee-bearing activities. For these banks, the decision to expand into nontraditional activities is possibly connected with reasons other than the effort to increase riskadjusted returns and is possibly influenced by external factors. This might be connected with the technological development and widespread deregulation that increased the competition among financial institutions, which in turn led to decreased cost advantages of banks. As a result, the profitability of banks' traditional activities dropped, which consequently led to an expansion of banking activities into non-traditional fee and commission-bearing services. An overall effort to find the optimal banking strategy and to identify the most appropriate level of bank fees can be observed.

Our study is motivated by the increasing share of NII in banks in recent years and the lack of literature dealing with this phenomenon in EU countries. Most of the current studies are based on US or individual countries' data from which it is not possible to draw a general conclusion about the EU banking market. In this paper, we use EU banks' data to analyse the links between bank NFCI magnitude, profitability, riskiness and riskadjusted profitability in the period 2005-2014. Based on the results, we make conclusions about the basic reasons why EU banks have increased their NII share in recent years. We also study whether the risk-return tradeoff (riskier activity - higher return) holds for NFCI.

The rest of the paper is structured as follows: Section 2 provides a literature review. In Section 3, we study the relationship between fee income magnitude and profitability, riskiness and risk-adjusted profitability of EU banks. Section 4 concludes.

\section{Literature Review}

Stiroh and Rumble (2006), Goddard et al. (2008), Sanya and Wolfe (2011), and Gürbüz et al. (2013) provide detailed literature reviews on the link between income diversification and bank performance. We discuss only the most important papers. Stiroh (2002), Stiroh (2004), DeYoung and Rice (2004) and Stiroh and Rumble (2006) conclude, based on US 
data, that diversification benefits might exist, but they are more than offset by the increased exposure to volatile NII-bearing activities and NII therefore tends to increase risk and decrease risk-adjusted profits.

Using data from OECD countries, Gischer and Jüttner (2003) discovered that higher fee-to-income ratios tend to decrease profitability, while Hahm (2008) and Moshirian et al. (2011) found an inverse effect of higher NII share. Higher reliance on non-traditional activities seems to increase the bank's profitability, but when also considering the macroeconomic factors, this relationship becomes weaker. Therefore, the revenue diversification does not necessarily imply a shift toward superior riskreturn frontiers. Baele et al. (2007), Lepetit et al. (2008), Köhler (2012), Chiorazzo et al. (2008), Busch and Kick (2015), Dietrich and Wanzenried (2011), Dumičić and Ridzak (2013), and Köhler (2013) tested the correlation between NII and performance based on EU banks' data. In European studies, the results seem to be highly different, and Köhler (2013) claims that the link is highly dependent on bank type.

Similar inconsistency of results can also be observed in studies of banking sectors in emerging economies. While Odesanmi and Wolfe (2007) found that diversification gains are present even though an increased share of NII lowers risk-adjusted profits, Sanya and Wolfe (2011) found that the impact of NII share on risk-adjusted performance differs across various model specifications. Nevertheless, a higher share of NII tends to decrease the insolvency risk. Conversely, Gamra and Plihon (2011) found that higher reliance on NII has a negative impact on risk-adjusted profitability and increases insolvency risk.

We conclude that, despite the theory of finance, which suggests that diversification should lead to better risk-return tradeoffs and economies of scope, many papers have found that expansion of non-traditional activities decreases, rather than improves, bank's risk-adjusted performance. This may be caused by the higher volatility of NII compared to interest income (DeYoung and Roland, 1999; Stiroh, 2002; Smith et al., 2003) or by the increasing correlation of NII with interest income (Stiroh, 2002). The diversification effect also depends on the actual portfolio held by the bank (Köhler, 2013) and it affects small and large banks differently (Goddard et al., 2008; Köhler, 2013). Despite the fact that the literature is not unanimous about the effects of income diversification, it is very important to study how non-traditional activities affect the risk and profitability of banks, because these are crucial indicators for bank managers.

\section{Empirical Analysis}

In this section, we examine the impact of the magnitude of NFCI on bank performance. In addition to the banks' basic interior factors, we include sector and country-specific variables as determinants of the profitability, riskiness and risk-adjusted profitability of banks. 


\subsection{Data set}

The analysis is based on EU data from 2005 to 2014. The data were taken from the Bankscope, Eurostat and ECB databases. The data set is a balanced panel including data from 329 EU banks (19 bank holdings and holding companies, 182 commercial, 57 savings, 45 cooperative, 17 real estate and mortgage and 9 investment banks). Table 1 displays the number of banks included in the study by country. ${ }^{2}$

Table 1: Number of banks included in the study by country

\begin{tabular}{lr|lr|lr|lr}
\hline Austria & 13 & Romania & 11 & Luxemburg & 1 & Hungary & 5 \\
\hline Estonia & 3 & Bulgaria & 8 & Slovenia & 5 & Netherlands & 8 \\
\hline Italy & 33 & France & 55 & Cyprus & 3 & Sweden & 37 \\
\hline Portugal & 11 & Lithuania & 5 & Greece & 1 & Denmark & 11 \\
\hline Belgium & 3 & Slovakia & 6 & Malta & 3 & Ireland & 1 \\
\hline Finland & 3 & Croatia & 15 & Spain & 12 & Poland & 13 \\
\hline Latvia & 8 & Germany & 6 & Czech Republic & 11 & United Kingdom & 38 \\
\hline
\end{tabular}

Source: Author

\subsection{Methodology}

We apply the System Generalized Method of Moments (GMM), which is appropriate for time-persistent data and data sets consisting of a large number of banks and a small number of time periods and is able to deal with explanatory variables that are not strictly exogenous.

The model is defined as:

$$
\begin{aligned}
& y_{i, t}=\alpha y_{i, t-1}+X_{i, t}^{\prime} \beta+\varepsilon_{i, t}, \\
& \varepsilon_{i, t}=\mu_{i}+v_{i, t}, \\
& E\left[\mu_{i}\right]=E\left[v_{i, t}\right]=E\left[\mu_{i} v_{i, t}\right]=0,
\end{aligned}
$$

where $|\alpha|<1, i=1, \ldots, N$ is an individual index and $t=1, \ldots, T$ is a time index. The disturbance is composed of the fixed effects, $\mu_{i}$, and the idiosyncratic shocks, $v_{i, t}$. Pooled OLS is

2 It was not possible to include more banks due to missing data. Moreover, we excluded banks with negative NFCI and operating income, because their NFCI/TI ratio would be misleading, and banks with negative Z-Scores, because we would not be able to construct the log transformation. 
inappropriate for the estimation because the exogeneity assumption is violated since $y_{i, t-1}$ and $\mu_{i}$ are correlated (Wooldridge, 2002). The least-squares dummy variable or within-groups estimator are unable to eliminate the dynamic panel bias (Nickell, 1981; Bond, 2002). It is suggested to use both the pooled OLS and the within-groups estimator as a robustness check, since both methods are biased in opposite directions (Bond, 2002). Two transformations are commonly used for dynamic panel data. The first method, Difference GMM, originally developed by Holtz-Eakin et al. (1988) and by Arellano and Bond (1991), uses the first-difference transformation applied to equation ((1). The fixed effects are no more present, but the lagged dependent variable is still endogenous, which can be addressed by assuming that $v_{i, t}$ are serially uncorrelated. The drawback of this method is that it does not allow for time-invariant variables.

The second method, System GMM, was developed by Blundell and Bond (1998), and it combines the differences equation with the level Equation (1). As long as $v_{i, t}$ are serially uncorrelated, the explanatory variables do not need to be strictly exogenous. Moreover, this method allows using time-invariant variables. The instruments are differenced to make them uncorrelated with the fixed effects (Sanya and Wolfe, 2011).

We include time dummies in the regressions because they make the assumption of no correlation between idiosyncratic shocks more likely to hold (Roodman, 2006; Sanya and Wolfe, 2011). We use a two-step System GMM with clustered standard errors robust to heteroskedasticity and autocorrelation within individuals, and with small sample corrections to the covariance matrix. We apply Windmeijer's (2005) correction to prevent the downward bias of the standard error estimations that may arise when the number of instruments is large (Arellano and Bond, 1991).

The estimation is performed in Stata. The estimation equation is:

$$
Y_{i, c, t}=\alpha+\beta Y_{i, c, t-1}+\gamma X_{i, c, t}+\delta Z_{c, t-1}+\epsilon W_{c, t}+\theta D_{i}+\vartheta T_{t}+\left(\mu_{i}+v_{i, c, t}\right),
$$

where:

$Y_{i, c, t} \quad$ performance of the bank $i$ in the country $c$ at the time $t$, measured as described in Section 3.3,

$Y_{i, c, t-1}$ performance of the bank $i$ in the country $c$ at the time $t-1$,

$X_{i, c, t}$ vector of bank-specific variables for the bank $i$ in the country $c$ at the time $t-1$,

$Z_{c, t-1}$ vector of country-specific variables for the country $c$ at the time $\mathrm{t}$,

$w_{c, t} \quad$ vector of banking sector-specific variables for the country $c$ at the time $t$,

$D_{i} \quad$ bank type dummy,

$T_{t} \quad$ time dummy,

$\mu_{i} \quad$ unobserved bank-specific time-invariant effect, and

$v_{i, c, t}$ disturbance term, which is independent across banks. 


\subsection{Variables}

The dependent variables capturing bank performance are:

- return on average assets (roaa): ROAA $_{i, t}=\frac{\text { Net income }_{i, t}}{\text { Average assets }_{i, t}}$,

- return on average equity (roae): $\operatorname{ROAE}_{i, t}=\frac{\text { Net }_{\text {income }} \text { Average equity }_{i, t}}{\text {, }}$

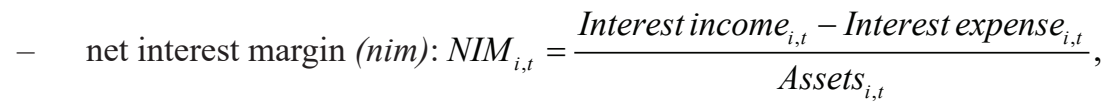

- risk-adjusted ROAA (raroaa) $:$ RAROAA $_{i, t}=\frac{R_{O A A_{i, t}}}{\sigma(R O A A)_{i}}$,

- risk-adjusted ROAE (raroae): $R A R O A E_{i, t}=\frac{R O A E_{i, t}}{\sigma(R O A E)_{i}}$,

- risk-adjusted NIM (ranim): RANIM $_{i, t}=\frac{N I M_{i, t}}{\sigma(N I M)_{i}}$,

- $\quad$ log-transformed Z-Score (ln_z_score $): \ln (Z-\text { Score })_{i, t}=\ln \left(\frac{\text { ROAA }_{i, t}+\frac{\text { Equity }_{t, i}}{\text { Assets }_{t, i}}}{\sigma\left(\text { ROAA }_{i}\right.}\right)$,

- $\quad$ log-transformed risk-adjusted equity to assets ratio $\left(\ln _{-} R A E A R\right)$ :

$$
\ln (\text { RAEAR })_{i, t}=\ln \left(\frac{\frac{\text { Equity }_{t, i}}{\text { Assets }_{t, i}}}{\sigma\left(\text { ROAA }_{i}\right.}\right)^{3}
$$

where $\sigma(.)_{i}$ stands for the standard deviation of each variable in the bank $i$, computed over the examined ten-year period.

ROAA, ROAE and NIM are standard measures of profitability. Nevertheless, since there is some risk-return tradeoff, it is important to measure the performance adjusted by risk. For this purpose, RAROAA, RAROAE and RANIM are constructed.

The literature on bank performance widely uses Z-Score as a measure of risk (Stiroh, 2002; Köhler, 2012). A higher Z-Score indicates a lower probability of insolvency. More precisely, it states how many standard deviations below the expected value the bank's profits (measured

3 Log-transformation is needed due to the high skewness of Z-Score and RAEAR. 
by ROAA) must fall in order to eliminate equity. Furthermore, we follow Köhler $(2012 ; 2013)$ and also use individual components of Z-Score that capture the portfolio and the leverage risk as risk indicators. The portfolio risk is measured by RAROAA, while RAEAR stands for the leverage risk. For both measures, higher values indicate increased stability.

Table 2: Independent variables

\begin{tabular}{|c|c|}
\hline Variable & Description \\
\hline nfci_ti & Net fee and commission income to total operating income \\
\hline depos_ass & Total customer deposits to asset ratio \\
\hline eq_ass & Total equity to total assets ratio \\
\hline loans_depos & Loans to deposits ratio \\
\hline losres_loans & Loan-loss reserves to gross loans ratio \\
\hline hi & Herfindahl index \\
\hline lag_gdp & Lagged real annual GDP growth rate \\
\hline lag_inf & Lagged annual inflation rate \\
\hline
\end{tabular}

Source: Author

By choosing the proper explanatory variables, we follow the actual best practice, which follows from the literature review in Section 2. Originally, we had 9 bank-specific, 3 sector-specific and 4 country-specific variables, but some of them had to be excluded due to their mutual correlation or insignificance. The independent variables used in the final analysis are summarized in Table 2.

We also include a lagged dependent variable (lag_DV) and bank-type dummy variables: dcom: 1 = commercial bank, dcoop: 1 = cooperative bank, $d s a v: 1=$ savings bank, dinv: 1 = investment bank, dhold: 1 = bank holdings and holding companies, and $0=$ real estate and mortgage banks.

\subsection{Descriptive analysis}

In this section, we provide a descriptive analysis of the variables used. The scatter plots depicting the relationship between the dependent variables and NFCI/TI can be found in Figure A.1. Figure 1 displays the mean of each dependent variable by bank type computed over the period 2005-2014. Cooperative banks seem to outperform the other banking models in terms of stability and risk-adjusted profitability. The opposite holds true for investment banks. This is probably due to the small number of investment banks 
included in the study and the fact that 7 out of the 9 investment banks are from PIIGS countries, which were the most affected by the 2008 financial crisis.

Figure 1: Average performance measures 2005-2014

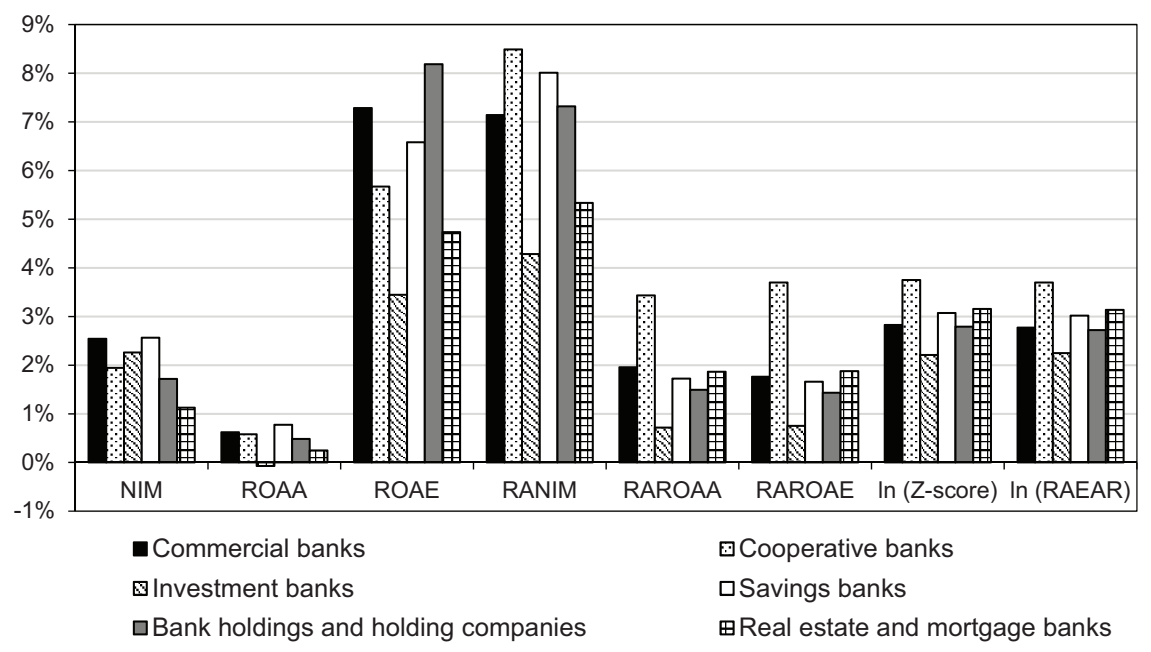

Note: For NIM, ROAA, ROAE, RANIM, RAROAA, and RAROAE, the values on the vertical axis are in \%. Source: Author, based on Bankscope

Figure 2: Development of average $\mathrm{NFCl} / \mathrm{TI}$

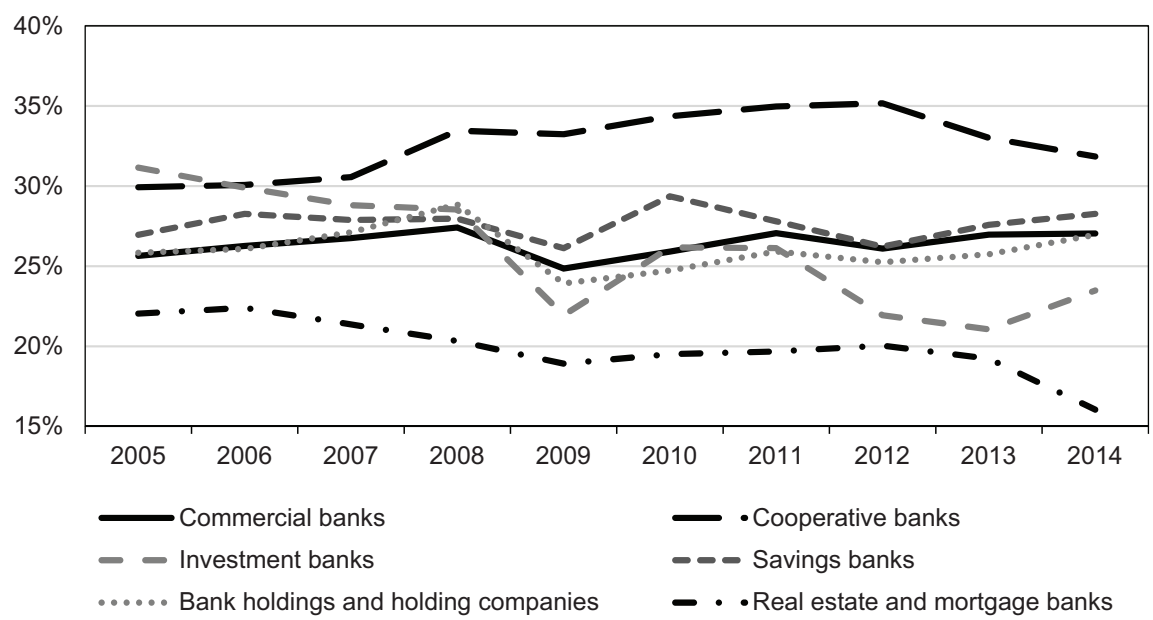

Source: Author, based on Bankscope

$4 \quad$ PIIGS refers to Portugal, Ireland, Italy Greece, Spain. 
The average NFCI/TI reported in the dataset during the analysed period was $27.11 \%$. The average NFCI/TI between 2005 and 2014 was the lowest in real estate and mortgage banks (20\%) and the highest in cooperative banks (32.66\%). Figure 2 shows that, after the financial crisis, most of the banks' NFCI/TI dropped by almost 3\%, but returned to the pre-crisis values within one year.

\section{Figure 3: Development of average ROAE}

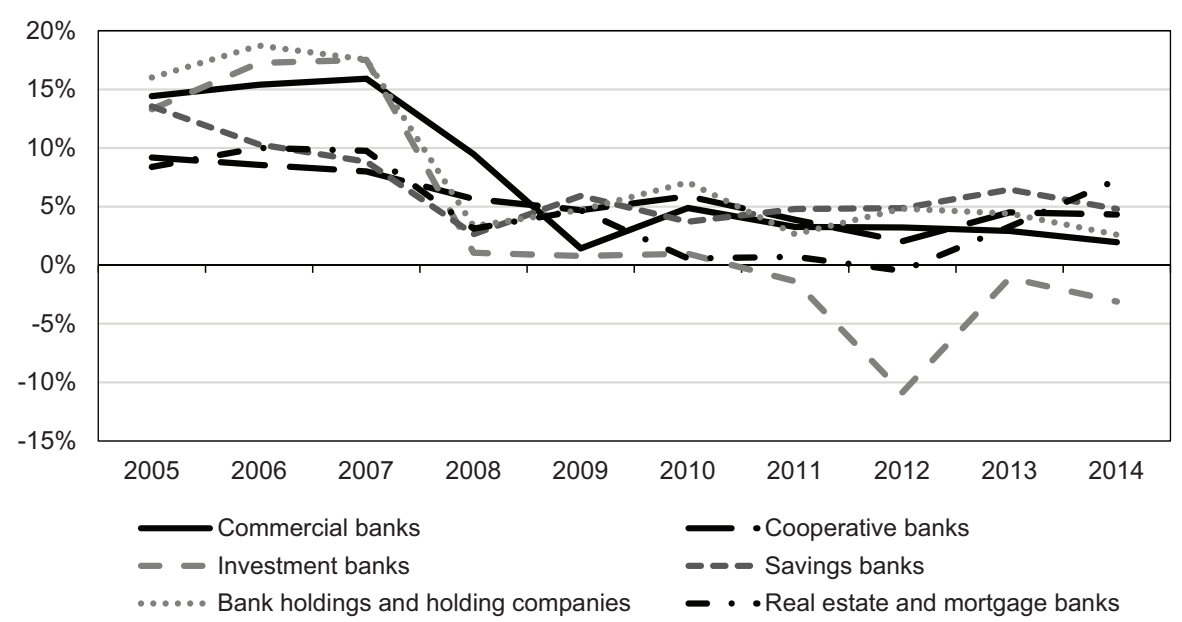

Source: Author, based on Bankscope

Figure 3 shows the evolution of the average ROAE from 2005 to 2014 by bank type. As seen, the ROAE dropped by approximately $10 \%$ in all bank types after the financial crisis in 2008 and remained at similar levels until 2014. The most pronounced decrease in the ROAE was observed in investment banks. Again, this could be related to the special features of the group, which is represented by a low number of banks, mainly from PIIGS countries.

Figure 4 shows that, compared to the ROAE, which decreased significantly after the crisis, the $\ln$ (Z-Score) was much more stable. In 2008, there was only a short-term deterioration in the $\ln$ (Z-Score) (i.e., an increase in the probability of insolvency).

Figure A. 2 shows the average NFCI/TI by country. The highest share of fee income was reported for 2005-2014 in Spain, while the lowest was reported in Ireland. Generally, the PIIGS countries reported extreme NFCI/TI on both sides compared to other EU countries. Figure A.3 shows the average Herfindahl index (HI) by country. On average, there is a moderate banking sector concentration in the EU. Figure A.4 shows countryspecific macroeconomic indicators in 2013. It can be seen that the macroeconomic 
conditions of the PIIGS countries are still very poor. This is reflected by very low or negative GDP growth rates. Table A.1 shows summary statistics of the variables used.

Figure 4: Development of average In (Z-Score)

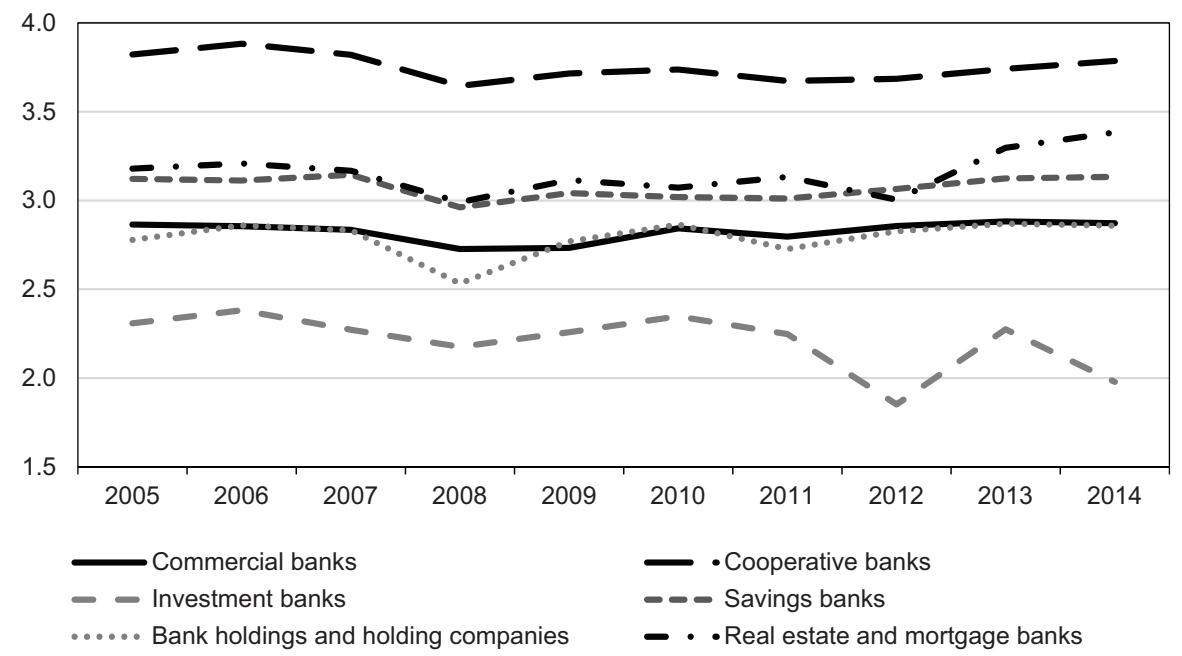

Source: Author based on Bankscope

\subsection{Results and findings}

The Wooldridge test for autocorrelation proved autocorrelation for all the dependent variables (Table 3). Therefore, System GMM will be used as the main estimation method. Other methods will be applied for a robustness check.

Table 3: Wooldridge test for autocorrelation

\begin{tabular}{l|c|c|c|c|c|c|c|c}
\hline & ROAA & ROAE & NIM & RAROAA & RAROAE & RANIM & In (Z-Score) & In (RAEAR) \\
\hline F statistics & 9.902 & 52.864 & 74.035 & 211.975 & 204.863 & 518.410 & 11.478 & 220.306 \\
\hline $\boldsymbol{p}$-value & 0.0018 & 0.0000 & 0.0000 & 0.0000 & 0.0000 & 0.0000 & 0.0008 & 0.0000 \\
\hline
\end{tabular}

Note: $H_{0}$ : No first-order autocorrelation, degrees of freedom (d.f. 1, 329)

Source: Author, based on Bankscope

The regression results of the model that investigates the determinants of profitability, riskiness and risk-adjusted profitability in EU banks can be found in Table 4. In all the regressions, the coefficient of lag_ $D V$ is significantly positive, proving the necessity 
of the application of an estimation method suitable for dynamic panel data. The firstorder autocorrelation in residuals is also proven by the Arellano-Bond AR (1) test. Moreover, the significant AR (2) test suggests that there may exist even longer time persistence in NIM and all risk-adjusted profitability measures, which was tested by the robustness tests. The results were not significantly influenced by the inclusion of higher lags of the dependent variable in the regressions. We instrument all endogenous and predetermined variables with their lagged values. In models with significant AR (2), higher lags of lag_ $D V$ were used as instruments because the second lag of the dependent variable is endogenous. The model is unlikely to suffer from overidentification because the Hansen test proves the exogeneity of instruments, and the rule of thumb that instruments should not exceed the number of groups is not violated. The significant F-test indicates the joint significance of the variables used in all models.

The effect of NFCI/TI on banks' performance is stable with the performance measure used. Not only does higher NFCI/TI decrease the profitability measured by NIM, ROAA and ROAE, but it also tends to increase the insolvency and portfolio risk, while the effect on leverage risk does not seem to be present. It is then straightforward that risk-adjusted performance measures are also deteriorated by higher fee income shares. We do not find any positive diversification effects from increasing fee income share. Therefore, the expansion into NFCI-bearing activities seems to be connected with external drivers rather than with the effort to achieve better risk-return tradeoffs. This might reflect the fact that higher NFCI/TI is connected with higher competition. Vozková and Teplý (2018) claim that competition pushes banks to offer more non-traditional fee income-bearing services, which are potentially riskier than the traditional ones. Moreover, competition decreases profitability, which might explain why increased NFCI is connected with both a decrease in profitability (general decrease in profitability due to competition) and an increase in riskiness (due to higher exposure to more volatile NFCI). Therefore, with increased NFCI share, we cannot observe the standard risk-return tradeoff. Nevertheless, it is possible that, without the expansion into fee-bearing activities, banks' performance would deteriorate due to high competition more than in cases of increased reliance on nontraditional activities. Therefore, the standard risk-return tradeoff is not generally rejected for NFCI.

The measure of liquidity, loans_depos, seems to have a significantly negative impact on ROAA, ROAE and risk-adjusted profitability measures, but the size of the coefficients is so small that we do not take them into consideration. Depos_ass has a positive impact on NIM, ROAE, RAROAA and ln (Z-Score), which proves that deposits count as rather cheap sources of funds, and this method of financing is connected with low risk. The coefficient of losres_loans is significantly negative in all the models, with 
the exception of NIM and RANIM, which supports the hypothesis that higher loan-loss reserves are a sign of poor quality of loans. As expected, higher eq_ass, a bank's ability to meet its obligations and absorb potential losses, increases the bank's stability.

$H_{i}$ has a significantly negative coefficient in almost all the performance models, but the coefficient is close to zero; therefore, market competition does not seem to play an important role in determining the performance of EU banks. This might be because, in almost all the EU countries, there is moderate market concentration (see Figure A.3). On the other hand, country-specific variables, as expected, seem to be very important. While higher GDP growth leads to better bank performance, inflation tends to have the opposite impact.

Business models influence the banks' profitability and stability. The highest profitability can be found in commercial and cooperative banks, while real estate and mortgage banks display lower profitability using all three measures. Using NIM, investment banks also have high profits while using ROAE, and bank holdings and holding companies seem to be the most profitable. Cooperative banks outperform the other types of banks in terms of risks and risk-adjusted profitability. These findings are in line with Figure 1.

To make the assumption of no correlation between idiosyncratic shocks more likely, we included time dummies for the years 2006 (t06) to $2013(t 13)^{5}$ in the estimation. The coefficients of the time dummies do not suggest any clear structural break. To formally test for structural break after the financial crisis, we performed separate regressions for the time periods 2005-2007 and 2008-2010. We did not find many significant differences among the results. Only the coefficient depos_ass in the NIM, ROAA, RANIM and $\ln$ (RAEAR) regressions in the time period 2008-2010 turned out to be significantly negative, which is not in line with our overall results. This might be because, after the crisis, there was a general drop in returns connected to traditional banking activities. Nevertheless, the coefficients of NFCI/TI, in which we are mainly interested, are consistently negative under all the specifications. During the crisis, the negative impact of the higher share of fee income on banks' performance increased slightly (see Table A.2). The missing evidence of a structural break in the impact of NFCI/TI on banks' performance during the crisis is probably because NFCI/TI measures relative, rather than absolute, values of fee income, and relative values are more stable over time.

5 More time dummies could not be included due to their mutual correlation. 
Table 4: Relationship between performance measures and NFCI/TI - System GMM regression results

\begin{tabular}{|c|c|c|c|c|c|c|c|c|}
\hline \multirow[b]{2}{*}{$\begin{array}{l}\text { Independent } \\
\text { variables }\end{array}$} & \multicolumn{8}{|c|}{ Dependent variables } \\
\hline & NIM & ROAA & ROAE & RANIM & RAROAA & RAROAE & In (Z-Score) & In (RAEAR) \\
\hline lag_DV & $\begin{array}{l}0.7725^{* * *} \\
(0.0000)\end{array}$ & $\begin{array}{l}0.3226^{* * *} \\
(0.0000)\end{array}$ & $\begin{array}{l}0.3521^{* * *} \\
(0.0000)\end{array}$ & $\begin{array}{l}0.9297^{* * *} \\
(0.0000)\end{array}$ & $\begin{array}{l}0.7258^{* * *} \\
(0.0000)\end{array}$ & $\begin{array}{l}0.6967^{* * *} \\
(0.0000)\end{array}$ & $\begin{array}{l}0.7665^{* * *} \\
(0.0000)\end{array}$ & $\begin{array}{l}0.8708^{* * *} \\
(0.0000)\end{array}$ \\
\hline nfci_ti & $\begin{array}{c}-0.0078^{* * *} \\
(0.0000)\end{array}$ & $\begin{array}{c}-0.0088^{* *} \\
(0.0230)\end{array}$ & $\begin{array}{l}-0.1652 * * * \\
(0.0000)\end{array}$ & $\begin{array}{c}-0.0115^{* *} \\
(0.0000)\end{array}$ & $\begin{array}{l}-0.0188^{* * *} \\
(0.0000)\end{array}$ & $\begin{array}{l}-0.0169 * * * \\
(0.0000)\end{array}$ & $\begin{array}{l}-0.0046^{* * *} \\
(0.0000)\end{array}$ & $\begin{array}{l}-0.0017^{* * *} \\
(0.0020)\end{array}$ \\
\hline loans_depos & $\begin{array}{l}-0.0000 \\
(0.2530)\end{array}$ & $\begin{array}{c}-0.0000 * * * \\
(0.0010)\end{array}$ & $\begin{array}{c}-0.0000^{* *} \\
(0.0120)\end{array}$ & $\begin{array}{c}0.0000 \\
(0.3770)\end{array}$ & $\begin{array}{l}-0.0000^{* * *} \\
(0.0000)\end{array}$ & $\begin{array}{l}-0.0000^{* * *} \\
(0.0000)\end{array}$ & $\begin{array}{c}0.0000 \\
(0.1520)\end{array}$ & $\begin{array}{c}0.0000 \\
(0.7360)\end{array}$ \\
\hline depos_ass & $\begin{array}{l}0.0022^{* *} \\
(0.0470)\end{array}$ & $\begin{array}{c}0,0005 \\
(0.8240)\end{array}$ & $\begin{array}{l}0.0629 * * \\
(0.0140)\end{array}$ & $\begin{array}{c}0,0022 \\
(0.1820)\end{array}$ & $\begin{array}{l}0.0050 * * \\
(0.0420)\end{array}$ & $\begin{array}{c}0,0042 \\
(0.1440)\end{array}$ & $\begin{array}{l}0.0025^{* *} \\
(0.0200)\end{array}$ & $\begin{array}{c}0.0000 \\
(0.8890)\end{array}$ \\
\hline losres_loans & $\begin{array}{c}0,0048 \\
(0.3950)\end{array}$ & $\begin{array}{l}-0.1297^{* * *} \\
(0.0000)\end{array}$ & $\begin{array}{l}-1.0478 * * * \\
(0.0000)\end{array}$ & $\begin{array}{l}-0,0098 \\
(0.1060)\end{array}$ & $\begin{array}{c}-0.0648^{* * *} \\
(0.0000)\end{array}$ & $\begin{array}{c}-0.0658^{* * *} \\
(0.0000)\end{array}$ & $\begin{array}{l}-0.0350^{* * *} \\
(0.0000)\end{array}$ & $\begin{array}{l}-0.0161^{* * *} \\
(0.0000)\end{array}$ \\
\hline eq_ass & $\begin{array}{l}0.0111^{* * *} \\
(0.0010)\end{array}$ & $\begin{array}{l}0.0340^{* *} \\
(0.0150)\end{array}$ & $\begin{array}{l}0.2117^{* * *} \\
(0.0070)\end{array}$ & $\begin{array}{l}0.0091^{*} \\
(0.0980)\end{array}$ & $\begin{array}{l}0.0176^{* *} \\
(0.0100)\end{array}$ & $\begin{array}{c}0.0111 \\
(0.1150)\end{array}$ & $\begin{array}{l}0.0227^{* * *} \\
(0.0000)\end{array}$ & $\begin{array}{l}0.0141^{* * *} \\
(0.0000)\end{array}$ \\
\hline hi & $\begin{array}{l}-0.0000 \\
(0.1850)\end{array}$ & $\begin{array}{c}-0.0000^{* *} \\
(0.0350)\end{array}$ & $\begin{array}{l}-0.0018^{* * *} \\
(0.0030)\end{array}$ & $\begin{array}{l}-0.0000 * * \\
(0.0190)\end{array}$ & $\begin{array}{l}-0.0002^{* * *} \\
(0.0000)\end{array}$ & $\begin{array}{l}-0.0002^{* * *} \\
(0.0000)\end{array}$ & $\begin{array}{l}-0.0001^{* * *} \\
(0.0000)\end{array}$ & $\begin{array}{c}-0.0000^{* * *} \\
(0.0000)\end{array}$ \\
\hline $\operatorname{lag} \_g d p$ & $\begin{array}{c}0.0308^{* * *} \\
(0.0000)\end{array}$ & $\begin{array}{l}0.0564^{* *} \\
(0.0110)\end{array}$ & $\begin{array}{l}0.3329 * * \\
(0.0150)\end{array}$ & $\begin{array}{c}0.0465^{* * *} \\
(0.0000)\end{array}$ & $\begin{array}{c}0,0071 \\
(0.5010)\end{array}$ & $\begin{array}{c}0,0044 \\
(0.6730)\end{array}$ & $\begin{array}{l}-0,0069 \\
(0.1240)\end{array}$ & $\begin{array}{l}-0,0013 \\
(0.5170)\end{array}$ \\
\hline lag_inf & $\begin{array}{c}0,0034 \\
(0.7060)\end{array}$ & $\begin{array}{l}-0.0596 * * * \\
(0.0080)\end{array}$ & $\begin{array}{l}-0.8312^{* * *} \\
(0.0010)\end{array}$ & $\begin{array}{l}-0.0577^{* * *} \\
(0.0000)\end{array}$ & $\begin{array}{l}-0.0906^{* * *} \\
(0.0000)\end{array}$ & $\begin{array}{l}-0.0884^{* * *} \\
(0.0000)\end{array}$ & $\begin{array}{l}-0.0331^{* * *} \\
(0.0000)\end{array}$ & $\begin{array}{l}-0.0116^{* * *} \\
(0.0000)\end{array}$ \\
\hline dcom & $\begin{array}{l}0.2462^{* * *} \\
(0.0000)\end{array}$ & $\begin{array}{l}0.5140^{* * *} \\
(0.0010)\end{array}$ & $\begin{array}{c}5.6076^{* * *} \\
(0.0010)\end{array}$ & $\begin{array}{c}0,0753 \\
(0.3940)\end{array}$ & $\begin{array}{l}0.3107^{* *} \\
(0.0300)\end{array}$ & $\begin{array}{l}0.2637^{*} \\
(0.0810)\end{array}$ & $\begin{array}{c}0,0175 \\
(0.7160)\end{array}$ & $\begin{array}{l}-0,0308 \\
(0.1910)\end{array}$ \\
\hline dcoop & $\begin{array}{l}0.2407^{* * *} \\
(0.0000)\end{array}$ & $\begin{array}{l}0.3959^{* *} \\
(0.0170)\end{array}$ & $\begin{array}{l}4.9246^{* * *} \\
(0.0080)\end{array}$ & $\begin{array}{c}0,1365 \\
(0.2680)\end{array}$ & $\begin{array}{l}0.6632^{* * *} \\
(0.0010)\end{array}$ & $\begin{array}{l}0.8077^{* * *} \\
(0.0000)\end{array}$ & $\begin{array}{l}0.1860 * * \\
(0.0140)\end{array}$ & $\begin{array}{c}0,0358 \\
(0.2730)\end{array}$ \\
\hline dsav & $\begin{array}{l}0.2203^{* * *} \\
(0.0000)\end{array}$ & $\begin{array}{l}0.2817^{*} \\
(0.0510)\end{array}$ & $\begin{array}{c}1,5128 \\
(0.4200)\end{array}$ & $\begin{array}{l}-0,0444 \\
(0.6850)\end{array}$ & $\begin{array}{l}-0,0835 \\
(0.5810)\end{array}$ & $\begin{array}{l}-0.0800 \\
(0.6230)\end{array}$ & $\begin{array}{l}-0.1045^{*} \\
(0.0720)\end{array}$ & $\begin{array}{l}-0.0755^{* * *} \\
(0.0050)\end{array}$ \\
\hline dinv & $\begin{array}{l}0.3737^{* * *} \\
(0.0060)\end{array}$ & $\begin{array}{c}0.2440 \\
(0.2180)\end{array}$ & $\begin{array}{l}5.6742 * * \\
(0.0330)\end{array}$ & $\begin{array}{c}0,1522 \\
(0.2890)\end{array}$ & $\begin{array}{c}0,0837 \\
(0.6660)\end{array}$ & $\begin{array}{c}0,0784 \\
(0.7390)\end{array}$ & $\begin{array}{l}-0,1403 \\
(0.1650)\end{array}$ & $\begin{array}{c}-0.1256^{* *} \\
(0.0210)\end{array}$ \\
\hline dhold & $\begin{array}{l}0.1960^{* * *} \\
(0.0070)\end{array}$ & $\begin{array}{l}0.4124^{* * *} \\
(0.0040)\end{array}$ & $\begin{array}{l}5.9953^{* * *} \\
(0.0010)\end{array}$ & $\begin{array}{c}0,1129 \\
(0.3990)\end{array}$ & $\begin{array}{c}0,1156 \\
(0.4610)\end{array}$ & $\begin{array}{c}0,0746 \\
(0.6570)\end{array}$ & $\begin{array}{c}0,0488 \\
(0.4020)\end{array}$ & $\begin{array}{l}-0,0194 \\
(0.5260)\end{array}$ \\
\hline t06 & $\begin{array}{l}-0.0926^{* *} \\
(0.0385)\end{array}$ & $\begin{array}{c}0.1566 \\
(0.1319)\end{array}$ & $\begin{array}{c}4.7983 \\
(0.8307)\end{array}$ & $\begin{array}{c}-0.4834^{*} \\
(0.0693)\end{array}$ & $\begin{array}{l}0.2466^{*} \\
(0.0808)\end{array}$ & $\begin{array}{l}{ }^{*} 0.3354 \\
(0.0871)\end{array}$ & $\begin{array}{l}-0.0038^{* *} \\
(0.0257)\end{array}$ & $\begin{array}{l}-0.0421^{* *} \\
(0.0145)\end{array}$ \\
\hline t07 & $\begin{array}{l}-0.0786^{* *} \\
(0.0449)\end{array}$ & $\begin{array}{c}0.0752 \\
(0.1573)\end{array}$ & $\begin{array}{c}4.2603 \\
(0.8778)\end{array}$ & $\begin{array}{c}-0.4148 * \\
(0.0782)\end{array}$ & $\begin{array}{c}0.2078 * \\
(0.0864)\end{array}$ & $\begin{array}{c}0.3358^{*} \\
(0.0919)\end{array}$ & $\begin{array}{l}-0.0206^{* *} \\
(0.0253)\end{array}$ & $\begin{array}{l}-0.0693^{* *} \\
(0.0119)\end{array}$ \\
\hline t08 & $\begin{array}{l}0.0262^{* *} \\
(0.0457)\end{array}$ & $\begin{array}{r}-0.4164 \\
(0.1721)\end{array}$ & $\begin{array}{c}-1.6203 \\
(0.9600)\end{array}$ & $\begin{array}{c}-0.1351^{*} \\
(0.0802)\end{array}$ & $\begin{array}{l}-0.7457 \\
(0.1029)\end{array}$ & $\begin{array}{l}-0.5256 \\
(0.1062)\end{array}$ & $\begin{array}{l}-0.1198^{* *} \\
(0.0295)\end{array}$ & $\begin{array}{l}-0.1127^{* *} \\
(0.0149)\end{array}$ \\
\hline t09 & $\begin{array}{l}-0.2013^{* *} \\
(0.0465)\end{array}$ & $\begin{array}{l}-0.1369 \\
(0.1170)\end{array}$ & $\begin{array}{l}-0.2901 \\
(0.9634)\end{array}$ & $\begin{array}{c}-0.4569 * \\
(0.0968)\end{array}$ & $\begin{array}{c}-0.0536^{*} \\
(0.0957)\end{array}$ & $\begin{array}{c}0.0573^{*} \\
(0.0988)\end{array}$ & $\begin{array}{c}0.0814^{* *} \\
(0.0288)\end{array}$ & $\begin{array}{l}0.0725^{* *} \\
(0.0150)\end{array}$ \\
\hline$t 10$ & $\begin{array}{c}0.1128^{* *} \\
(0.0436)\end{array}$ & $\begin{array}{c}0.2412^{*} \\
(0.0954)\end{array}$ & $\begin{array}{c}2.5988 \\
(1.0756)\end{array}$ & $\begin{array}{l}0.0243^{*} \\
(0.0873)\end{array}$ & $\begin{array}{c}0.1989 * \\
(0.0915)\end{array}$ & $\begin{array}{c}0.1826^{*} \\
(0.0866)\end{array}$ & $\begin{array}{l}-0.0178^{* *} \\
(0.0338)\end{array}$ & $\begin{array}{l}-0.0164^{* *} \\
(0.0168)\end{array}$ \\
\hline t11 & $\begin{array}{l}-0.0428^{* *} \\
(0.0358)\end{array}$ & $\begin{array}{l}-0.1238 \\
(0.1154)\end{array}$ & $\begin{array}{l}-0.4779 \\
(0.7681)\end{array}$ & $\begin{array}{l}-0.1201^{*} \\
(0.0624)\end{array}$ & $\begin{array}{c}-0.1095^{*} \\
(0.0717)\end{array}$ & $\begin{array}{c}-0.0334^{*} \\
(0.0704)\end{array}$ & $\begin{array}{l}-0.0253^{* *} \\
(0.0232)\end{array}$ & $\begin{array}{l}-0.0447^{* *} \\
(0.0110)\end{array}$ \\
\hline t12 & $\begin{array}{l}-0.1563^{* *} \\
(0.0319)\end{array}$ & $\begin{array}{l}-0.1270 \\
(0.1560)\end{array}$ & $\begin{array}{c}0.5620 \\
(0.9389)\end{array}$ & $\begin{array}{c}-0.4323^{*} \\
(0.0650)\end{array}$ & $\begin{array}{c}-0.0931^{*} \\
(0.0847)\end{array}$ & $\begin{array}{c}-0.0284^{*} \\
(0.0829)\end{array}$ & $\begin{array}{c}0.0703^{* *} \\
(0.0320)\end{array}$ & $\begin{array}{l}0.0333^{* *} \\
(0.0113)\end{array}$ \\
\hline$t 13$ & $\begin{array}{l}-0.0613^{* *} \\
(0.0295)\end{array}$ & $\begin{array}{l}0.3003^{*} \\
(0.0883)\end{array}$ & $\begin{array}{c}2.4410 \\
(0.8299)\end{array}$ & $\begin{array}{l}-0.1728^{*} \\
(0.0579)\end{array}$ & $\begin{array}{l}0.2702^{*} \\
(0.0791)\end{array}$ & $\begin{array}{l}0.2840 * \\
(0.0749)\end{array}$ & $\begin{array}{c}0.0893^{* *} \\
(0.0244)\end{array}$ & $\begin{array}{l}0.0269 * * * \\
(0.0097)\end{array}$ \\
\hline _cons & $\begin{array}{l}0.2536 * * * \\
(0.0030)\end{array}$ & $\begin{array}{l}0.4331^{* * *} \\
(0.0080)\end{array}$ & $\begin{array}{c}3,6246 \\
(0.1150)\end{array}$ & $\begin{array}{l}0.9152 * * * \\
(0.0000)\end{array}$ & $\begin{array}{l}0.9108 * * * \\
(0.0000)\end{array}$ & $\begin{array}{l}0.9279 * * * \\
(0.0000)\end{array}$ & $\begin{array}{l}0.7604^{* * *} \\
(0.0000)\end{array}$ & $\begin{array}{l}0.4821 * * * \\
(0.0000)\end{array}$ \\
\hline
\end{tabular}




\begin{tabular}{|c|c|c|c|c|c|c|c|c|}
\hline \multicolumn{9}{|c|}{ Estimation diagnostics } \\
\hline $\begin{array}{l}\text { Number } \\
\text { of observations }\end{array}$ & 2961 & 2961 & 2961 & 2961 & 2961 & 2961 & 2961 & 2961 \\
\hline $\begin{array}{l}\text { Number } \\
\text { of instruments }\end{array}$ & 317 & 326 & 326 & 317 & 317 & 317 & 326 & 326 \\
\hline F-test & $278.81^{* * *}$ & $34.72^{* * *}$ & $49.85^{* * *}$ & $378.54^{* * *}$ & $110.73^{* * *}$ & $106.57^{* * *}$ & $295.51^{* * *}$ & $740.74 * * *$ \\
\hline $\begin{array}{l}\text { Arellano-Bond } \\
\text { AR (1) }\end{array}$ & $-4.94^{* * *}$ & $-2.5^{* *}$ & $-5.18^{* * *}$ & $-10.73^{* * *}$ & $-11.55^{* * *}$ & $-11.24^{* * *}$ & $-2.81^{* * *}$ & $-8.55^{* * *}$ \\
\hline $\begin{array}{l}\text { Arellano-Bond } \\
\text { AR (2) }\end{array}$ & $-2.5^{* *}$ & 0.2 & 0.22 & $-4.94^{* * *}$ & $2.94^{* * *}$ & $3.96^{* * *}$ & 1.33 & 0.05 \\
\hline Hansen test & 321.49 & 323.46 & 324.92 & 319.02 & 321.12 & 319.47 & 322.55 & 322.68 \\
\hline
\end{tabular}

Note: Robust standard errors adjusted for 329 clusters in the index are in parentheses, ${ }^{* * *} / * * / *$ indicates significance at $1 \% / 5 \% / 10 \%$,_cons stands for constant

Source: Author based on Bankscope, Eurostat, ECB

In addition to including higher lags in the NIM and risk-adjusted profitability regressions and testing the crisis period separately, we also performed robustness tests among the regressions by excluding investment banks, since they are outlying in some aspects. Since it is very difficult to stipulate the ideal number of instruments in System GMM, a part of the robustness check comprises regressions estimating the same model using other/fewer instruments. The results proved to be robust to these changes. Moreover, the System GMM results proved to be valid, since the estimate of the lagged dependent variable lies between the FE and pooled OLS estimate (see Table A.3).

\subsubsection{Summary and comparison of results}

Table 5 provides the comparison of our results with the current literature. Most of the other academic papers examined the impact of NII and not just NFCI on the bank performance. Nevertheless, we believe the results may be compared because NFCI represents the greatest part of NII in most of the banks.

It can be seen that the literature is not unanimous about the link between fee income and bank performance. The greatest disunity is found by RAROAA and Z-Score, where all the possible outcomes were found in similar quantities. The relationship is probably highly dependent on other internal and external conditions faced by the bank. In ourstudy, NFCI/TI has a negative impact on all the profitability, stability and risk-adjusted profitability measures. The performance of EU banks seems to decrease with increased reliance on NFCI. The link between NFCI/TI and ROAA, RAEAR was insignificant under some model specifications tested among the robustness tests. Interestingly, only one paper listed below tested the impact of NII or fee income share on RANIM. This may be 
because NIM is, compared to other profitability measures, more stable and thus riskadjusting may not be as important. Nevertheless, we constructed the RANIM measure and found that fee income not only decreases NIM but also decreases RANIM.

Table 5: Comparison of results with existing literature

\begin{tabular}{|c|c|c|c|c|c|c|c|c|}
\hline \multirow[b]{2}{*}{ Author } & \multicolumn{8}{|c|}{ Dependent variables } \\
\hline & ROAA & ROAE & $N I M$ & RAROAA & RAROAE & RANIM & Z-Score & RAEAR \\
\hline Stiroh (2002) & & 0 & & & - & & - & \\
\hline Gischer and Jüttner (2003) & - & & - & & & & & \\
\hline DeYoung and Rice (2004) & & + & & & - & & & \\
\hline Stiroh (2004) & & & & -10 & - & & $-/ 0$ & \\
\hline Stiroh and Rumble (2006) & 0 & 0 & & - & - & & - & \\
\hline Odesanmi and Wolfe (2007) & & & & - & - & & & \\
\hline Goddard et al. (2008) & 0 & + & & 0 & 0 & & & \\
\hline Chiorazzo et al. (2008) & & & & + & + & & & \\
\hline Hahm (2008) & $+/ 0$ & & & & & & 0 & \\
\hline Lepetit et al. (2008) & & & - & & & & & \\
\hline Busch and Kick (2009) & + & + & & + & + & & & \\
\hline Dietrich and Wanzenried (2011) & + & + & + & & & & & \\
\hline Gamra and Plihon (2011) & & & & - & - & & - & \\
\hline Moshirian et al. (2011) & + & & & & & & & \\
\hline Sanya and Wolfe (2011) & & & & $+/-/ 0$ & $+/-/ 0$ & & + & \\
\hline Köhler (2012) & & & & + & & + & + & \\
\hline Dumičić and Ridzak (2013) & & & - & & & & & \\
\hline Köhler (2013) & & & & $+/ 0$ & $+/-/ 0$ & & $+/ 0$ & + \\
\hline This study & $-/ 0$ & - & - & - & - & - & - & -10 \\
\hline
\end{tabular}

Note: + /- indicates a statistically positive/negative coefficient at the $10 \%$ level or better; 0 indicates insignificant coefficients; in case the results changed under different model specifications or in robustness tests, there are more results reported in one cell; in the case of absence of the variable in the given study the cell is left blank.

Source: Author based on individual papers and own results 
Our evidence of the negative impact of NFCI/TI on banks' performance is against the results found in Dietrich and Wanzenried (2011), who performed the analysis based on Swiss banks; Chiorazzo et al. (2008), who used data from Italian banks; and Busch and Kick (2009) and Köhler (2012; 2013), who used data from German banks. This might be because those studies made their analysis using data from only one country. Sanya and Wolfe (2011) analysed the link in emerging economies and found that the result is heavily dependent on the exact model specification. Most of the other studies were based on US data or included banks from different countries. Our results are in line with those that show that the relationship between fee income share and banks' performance is negative.

There are two further key research opportunities resulting from our paper. First, the diversity of banking models and banking market fragmentation should beanalysed in more detail. The exact impact of the fee income share depends on the business model and the bank size. Whereas traditional banks mainly dependent on interest income can possibly gain by increasing their NFCI, non-traditional banks should instead rely more on interest income to stabilize their profits. Second, since some variables needed to be excluded due to their mutual correlation, other measures capturing bank, sector and country-specific factors should be included in the model.

\section{Conclusion}

In this paper, we contributed to the existing literature by studying the impact of NFCI on banks' performance in the EU using a unique cross-country data set. From the results, we are able to draw conclusions about the reasons why EU banks expand into non-traditional fee-bearing activities, and we fill a gap in the literature dealing with drivers of bank business model changes. Fee income represents almost $30 \%$ of the total income of EU banks, and it is therefore crucial to set and maintain an appropriate fee policy. However, both theoretical and empirical evidence about the optimal level of fee income is mixed.

We used balanced panel data form 329 EU banks during the period 2005-2014. We employed the System GMM estimation method, since it is suitable for dynamic panel data. Different bank-specific, banking sector-specific and macroeconomic factors were considered. We were primarily concerned with the relationship between fee income magnitude and banks' performance, which was measured by different profitability, risk and risk-adjusted profitability measures. The analysis suggests that banks depending more on fee income tend to be less profitable and riskier. We did not find any diversification benefits. Based on this result, we claim that substantial levels of fee income might be the result of the effort to maintain sufficient profitability in increasingly competitive markets, rather than the attempt to diversify. Moreover, non-traditional activities are 
potentially riskier than traditional banking activities. Nevertheless, increasing the share of fee income might lead to increased stability in banks that rely solely or heavily on interest income. On the other hand, investment banks should instead rely more on interest income to stabilize their profits. Our results suggest that EU banks are already universal enough, and therefore the current shift in fee income share does not lead to increased risk-adjusted profitability.

Our results confirm that the share of fee income is highly dependent on the banks' business models, as well as on market conditions. Deposits seem to represent a cheap and not very risky source of finance, since they improve NIM and ROAE and simultaneously decrease insolvency risk. A higher ratio of loan-loss reserves to total loans, a sign of poor quality of provided loans, has a negative impact on all performance measures, which is in line with our expectations. As expected, greater reliance on equity financing leads to higher stability in banks. Among macroeconomic conditions, both GDP growth and inflation significantly affect banks' performance.

\section{Appendix}

Figure A.1: Scatter plots
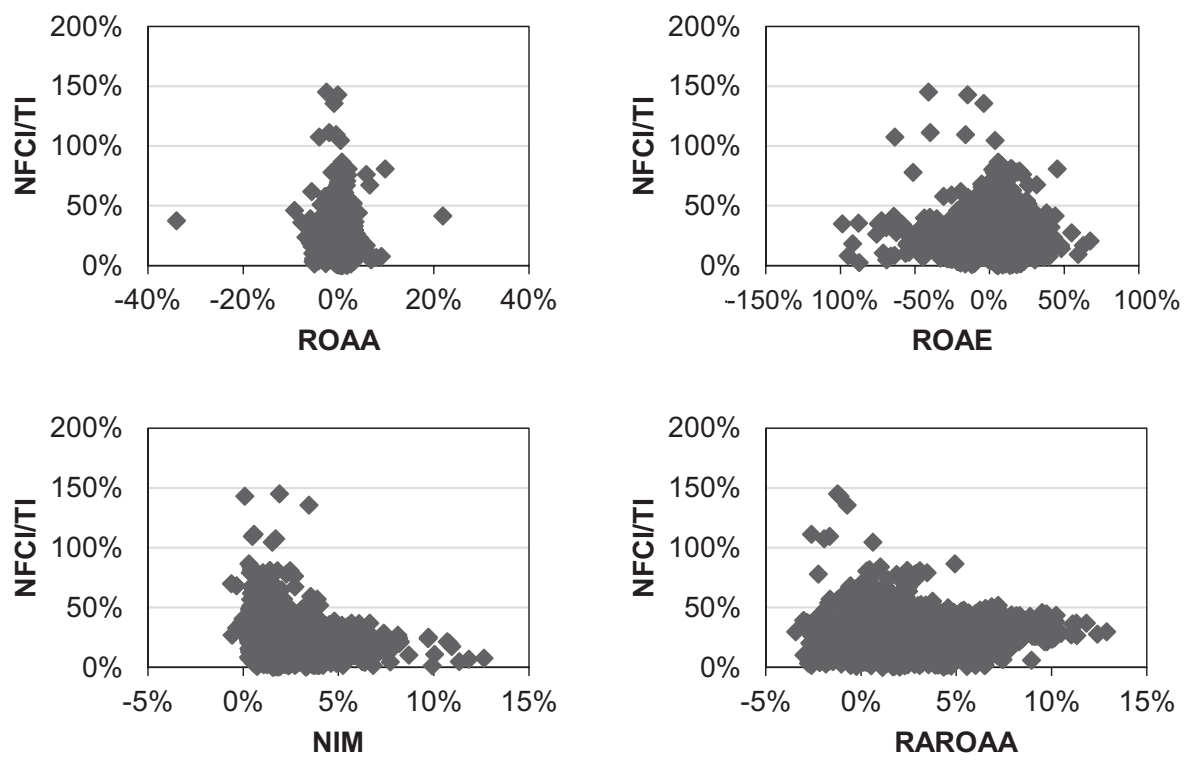
Figure A.1: Continuation
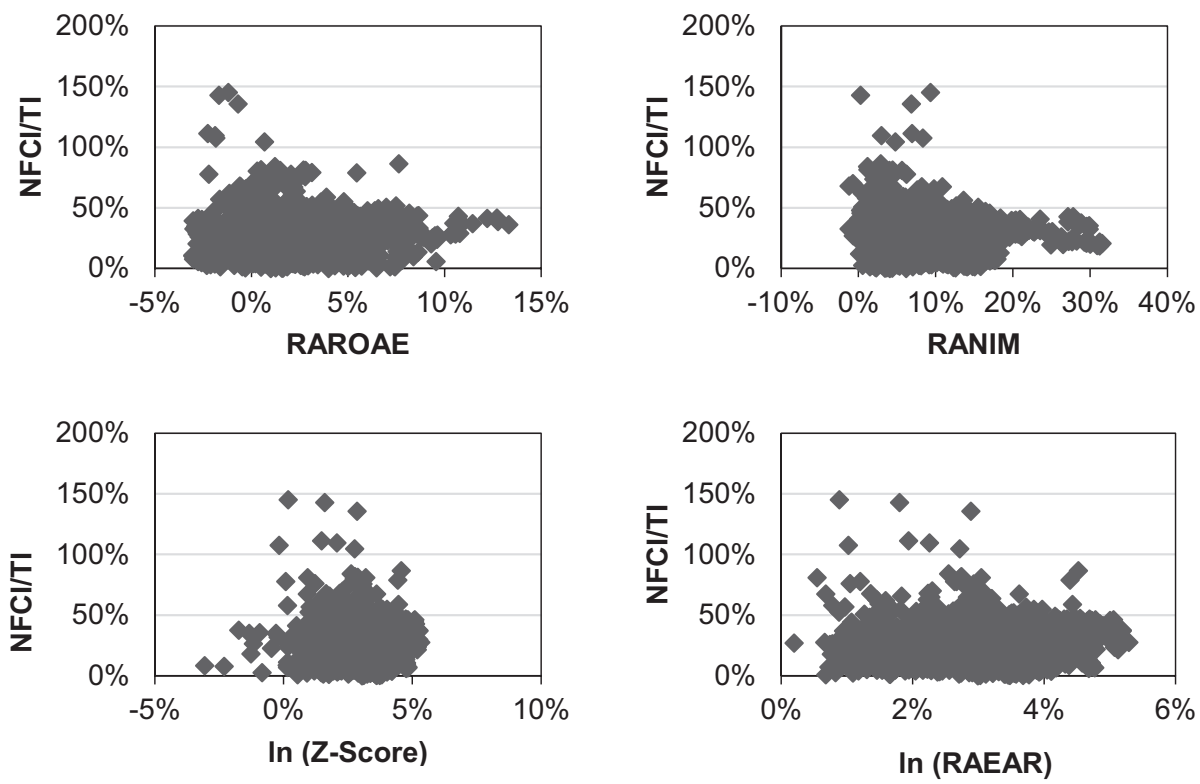

Source: Author, based on Bankscope

Figure A.2: Average NFCl/TI 2005-2014

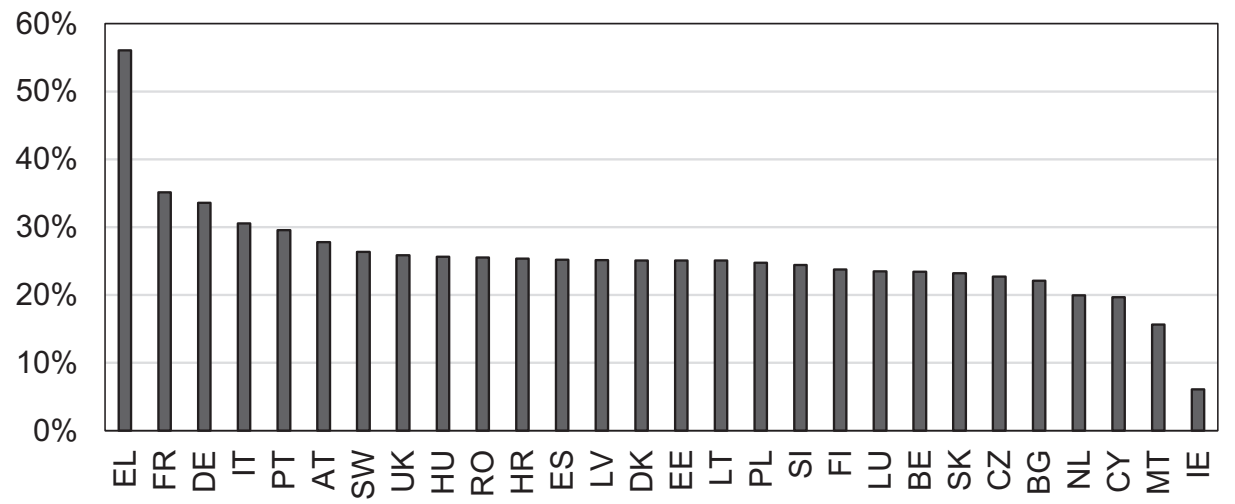

Source: Author, based on Bankscope 
Figure A.3: Average HI 2005-2014

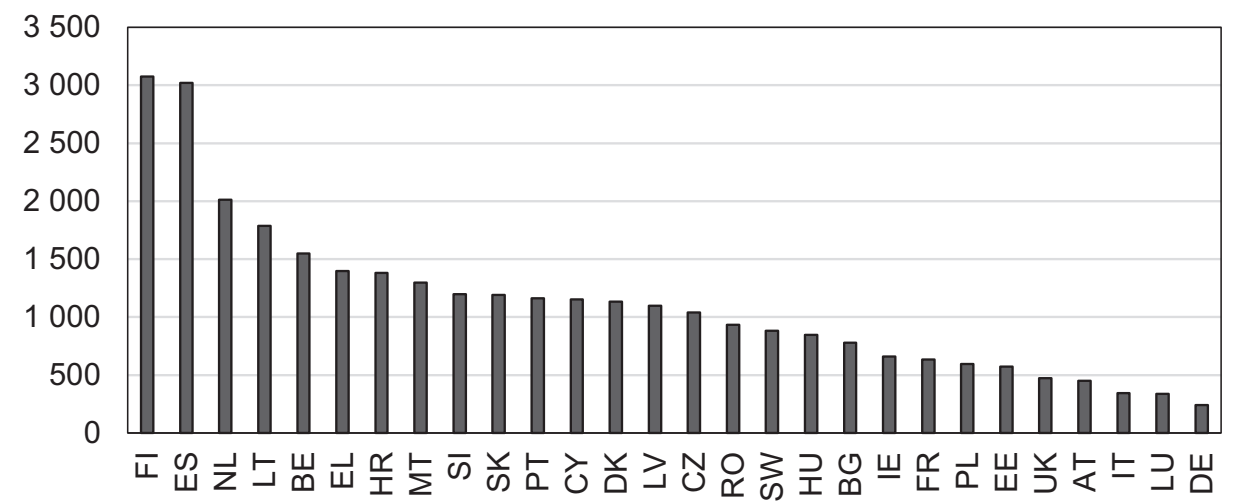

Note: $\mathrm{HI}$ 's values range between $0-10,000$; higher values of $\mathrm{HI}$ stand for higher concentration Source: Author, based on the ECB

Figure A.4: Macroeconomic indicators in 2013

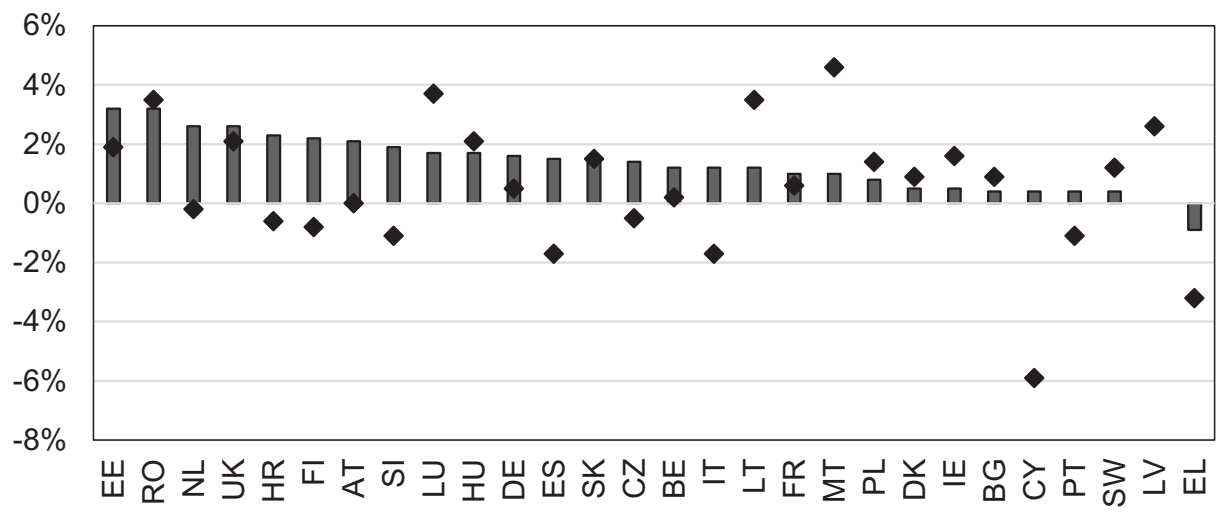

$\square$ Annual inflation rate $\bullet$ Real annual GDP growth

Source: Author, based on Eurostat, ECB 
Table A.1: Summary statistics

\begin{tabular}{|c|c|c|c|c|c|}
\hline Variable & Min & 1st quartile & Median & 3rd quartile & $\operatorname{Max}$ \\
\hline roae & $-98.82 \%$ & $3.7 \%$ & $7.24 \%$ & $12.41 \%$ & $67.29 \%$ \\
\hline roaa & $-34.03 \%$ & $0.25 \%$ & $0.59 \%$ & $1.05 \%$ & $21.91 \%$ \\
\hline nim & $-0.62 \%$ & $1.4 \%$ & $2.12 \%$ & $2.96 \%$ & $12.63 \%$ \\
\hline raroae & $-3.05 \%$ & $0.5 \%$ & $1.51 \%$ & $3.1 \%$ & $13.31 \%$ \\
\hline raroaa & $-3.43 \%$ & $0.53 \%$ & $1.6 \%$ & $3.16 \%$ & $12.89 \%$ \\
\hline ranim & $-1.21 \%$ & $4.42 \%$ & $6.47 \%$ & $8.99 \%$ & $31.53 \%$ \\
\hline In_z_score & -3.08 & 2.45 & 3.03 & 3.6 & 5.33 \\
\hline In_raear & 0.2 & 2.38 & 2.95 & 3.51 & 5.29 \\
\hline$n f c i+t i$ & $0 \%$ & $19.95 \%$ & $26.38 \%$ & $33.44 \%$ & $145.13 \%$ \\
\hline loans_depos & $4.49 \%$ & $82.22 \%$ & $107.81 \%$ & $153.57 \%$ & $1,000,000 \%$ \\
\hline depos_ass & $0.01 \%$ & $36.78 \%$ & $55.57 \%$ & $74.14 \%$ & $96.16 \%$ \\
\hline losres_loans & $0.01 \%$ & $1.18 \%$ & $2.39 \%$ & $4.06 \%$ & $41.87 \%$ \\
\hline eq_ass & $1.08 \%$ & $5.78 \%$ & $8.16 \%$ & $11.73 \%$ & $71.4 \%$ \\
\hline hi & 174 & 523 & 726 & 1061 & 4039 \\
\hline $\operatorname{lag} g d p$ & $-14.8 \%$ & $0.2 \%$ & $1.7 \%$ & $3.1 \%$ & $11.9 \%$ \\
\hline lag_inf & $-1.7 \%$ & $1.6 \%$ & $2.2 \%$ & $3.2 \%$ & $15.3 \%$ \\
\hline
\end{tabular}

Source: Author, based on Bankscope, Eurostat, ECB

Table A.2: Check for presence of structural break

\begin{tabular}{l|c|c|c|c|c|c|c|c}
\hline & \multicolumn{7}{|c}{ Dependent variable } \\
\hline $\mathbf{N F C I} / \mathrm{TI}$ & NIM & ROAA & ROAE & RANIM & RAROAA & RAROAE & In (Z-Score) & In (RAEAR) \\
\hline $\mathbf{2 0 0 5}-$ & $-0.0205^{* *}$ & $-0.0073^{* * *}$ & -0.2173 & $-0.0466^{* *}$ & $-0.0391^{* *}$ & $-0.0270^{* *}$ & $-0.0063^{* *}$ & $-0.0033^{* * *}$ \\
$\mathbf{2 0 0 7}$ & $(0.0073)$ & $(0.0094)$ & $(0.1420)$ & $(0.0128)$ & $(0.0147)$ & $(0.0168)$ & $(0.0039)$ & $(0.0049)$ \\
\hline $\mathbf{2 0 0 8 -}$ & $-0.0372^{* *}$ & $-0.0087^{* *}$ & -0.3897 & $-0.0738^{* *}$ & $-0.0364^{* *}$ & $-0.0463^{* *}$ & $-0.0195^{* * *}$ & $-0.0070^{* * *}$ \\
$\mathbf{2 0 1 0}$ & $(0.0120)$ & $(0.0231)$ & $(0.2778)$ & $(0.0466)$ & $(0.0305)$ & $(0.0330)$ & $(0.0079)$ & $(0.0070)$ \\
\hline
\end{tabular}

Note: Robust standard errors adjusted for 329 clusters in index are in parentheses, ${ }^{* * * * *} / *$ indicates significance at $1 \% / 5 \% / 10 \%$, other independent variables included in the regression are not reported Source: Author, based on Bankscope, Eurostat, ECB 


\begin{tabular}{|c|c|c|c|c|c|c|c|c|}
\hline \multirow[b]{2}{*}{ lag_DV } & \multicolumn{8}{|c|}{ Dependent variable } \\
\hline & NIM & ROAA & ROAE & RANIM & RAROAA & RAROAE & In (Z-Score) & In (RAEAR) \\
\hline $\begin{array}{l}\text { pooled } \\
\text { OLS }\end{array}$ & $\begin{array}{l}0.8405^{* * *} \\
(0.0000)\end{array}$ & $\begin{array}{l}0.4342^{* * *} \\
(0.0000)\end{array}$ & $\begin{array}{l}0.4705^{* * *} \\
(0.0000)\end{array}$ & $\begin{array}{l}0.9813^{* * *} \\
(0.0000)\end{array}$ & $\begin{array}{l}0.8713^{* * *} \\
(0.0000)\end{array}$ & $\begin{array}{l}0.8499 * * * \\
(0.0000)\end{array}$ & $\begin{array}{l}0.9217^{* * * *} \\
(0.0000)\end{array}$ & $\begin{array}{l}0.9626^{* * *} \\
(0.0000)\end{array}$ \\
\hline $\begin{array}{l}\text { System } \\
\text { GMM }\end{array}$ & $\begin{array}{l}0.7725^{* * *} \\
(0.0000)\end{array}$ & $\begin{array}{l}0.3226^{* * *} \\
(0.0000)\end{array}$ & $\begin{array}{l}0.3521^{* * *} \\
(0.0000)\end{array}$ & $\begin{array}{l}0.9297^{* * *} \\
(0.0000)\end{array}$ & $\begin{array}{l}0.7258^{* * *} \\
(0.0000)\end{array}$ & $\begin{array}{l}0.6967^{* * *} \\
(0.0000)\end{array}$ & $\begin{array}{l}0.7665^{* * *} \\
(0.0000)\end{array}$ & $\begin{array}{l}0.8708^{* * *} \\
(0.0000)\end{array}$ \\
\hline FE & $\begin{array}{l}0.5804^{* * *} \\
(0.0000)\end{array}$ & $\begin{array}{l}0.2047^{* * *} \\
(0.0000)\end{array}$ & $\begin{array}{l}0.1419 * * * \\
(0.0000)\end{array}$ & $\begin{array}{l}0.4584^{* * *} \\
(0.0000)\end{array}$ & $\begin{array}{l}0.1525^{* * *} \\
(0.0000)\end{array}$ & $\begin{array}{l}0.1646 * * * \\
(0.0000)\end{array}$ & $\begin{array}{c}0.0698 \\
(0.1800)\end{array}$ & $\begin{array}{l}0.2730 * * * \\
(0.0000)\end{array}$ \\
\hline
\end{tabular}

Note: Robust standard errors adjusted for 329 clusters in index are in parentheses, ${ }^{* * *} / * * *$ indicates significance at $1 \% / 5 \% / 10 \%$, other independent variables included in the regression are not reported Source: Author, based on Bankscope, Eurostat, ECB

\section{References}

Arellano, M., Bond, S. (1991). Some Tests of Specification for Panel Data: Monte Carlo Evidence and an Application to Employment Equations. Review of Economic Studies, 58(2), 277-297, https://doi.org/10.2307/2297968

Baele, L., DeJonghe, O., Vennet, R. V. (2007). Does the Stock Market Value Bank Diversification? Journal of Banking and Finance, 31(7), 1999-2023, https://doi.org/10.1016/j. jbankfin.2006.08.003

Blundell, R., Bond, S. (1998). Initial Conditions and Moment Restrictions in Dynamic Panel Data Models. Journal of Econometrics, 87(1), 115-143, https://doi.org/10.1016/ s0304-4076(98)00009-8

Bond, S. (2002). Dynamic Panel Data Models: A Guide to Micro Data Methods and Practice. Portuguese Economic Journal, 1(2), 141-162, https://doi.org/10.1007/s10258-002-0009-9

Brighi, P., Venturelli, V. (2016). How Functional and Geographic Diversification Affect Bank Profitability during the Crisis. Finance Research Letters, 16, 1-10, https://doi.org/10.1016/j.frl.2015.10.020

Busch, R., Kick, T. (2015). Income Structure and Bank Business Models: Evidence on Performance and Stability from the German Banking Industry. Schmalenbach Business Review, 67(2), 226-253, https://doi.org/10.1007/bf03396875

Chiorazzo, V., Milani, C., Salvini, F. (2008). Income Diversification and Bank Performance: Evidence from Italian Banks. Journal of Financial Services Research, 33(3), 181-203, https://doi.org/10.1007/s10693-008-0029-4 
DeYoung, R., Rice, T. (2004). Noninterest Income and Financial Performance at U.S. Commercial Banks. The Financial Review, 39(1), 101-127, https://doi. org/10.1111/j.0732-8516.2004.00069.x

DeYoung, R., Roland, K. P. (2001). Product Mix and Earnings Volatility at Commercial Banks: Evidence from a Degree of Leverage Model. Journal of Financial Intermediation, 10(1), 54-84, https://doi.org/10.1006/jfin.2000.0305

Dietrich, A., Wanzenried, G. (2011). Determinants of Bank Profitability before and During the Crisis: Evidence from Switzerland. Journal of International Financial Markets, Institutions and Money, 21(3), 307-327, https://doi.org/10.1016/j.intfin.2010.11.002

Dumičić, M., Ridzak, T. (2013). Determinants of Banks' Net Interest Margins in Central and Eastern Europe. Financial Theory and Practice, 37(1), 1-30, https://doi.org/10.3326/ fintp.37.1.1

ECB (2016). Financial Stability Review. November 2016.

Elsas, R., Hackethal, A., Holzhäuser, M. (2010). The Anatomy of Bank Diversification. Journal of Banking and Finance, 34(6), 1274-1287, https://doi.org/10.1016/j.jbankfin.2009.11.024

Gamra, S. B., Plihon, D. (2011). Revenue Diversification in Emerging Market Banks: Implications for Financial Performance. [Retrieved 2017-11-9] Available at: http://arxiv.org/ pdf/1107.0170

Gischer, H., Jüttner, D. J. (2003). Global Competition, Fee Income and Interest Rate Margins of Banks. Kredit und Kapital, 36(3), 368-394.

Goddard, J., McKillop, D., Wilson, J. O. S. (2008). The Diversification and Financial Performance of US Credit Unions. Journal of Banking and Finance, 32(9), 1836-1849, https://doi.org/10.1016/j.jbankfin.2007.12.015

Gürbüz, A. O., Yanik, S., Aytürk, Y. (2013). Income Diversification and Bank Performance: Evidence from Turkish Banking Sector. Journal of BRSA Banking and Financial Markets, 7(1), 9-29.

Hahm, J. H. (2008). Determinants and Consequences of Non-Interest Income Diversification of Commercial Banks in OECD Countries. East Asian Economic Review, 12(1), 3-31, https://doi.org/10.11644/kiep.jeai.2008.12.1.178

Holtz-Eakin, D., Newey, W., Rosen, H. S. (1988). Estimating Vector Autoregression with Panel Data. Econometrica, 56(6), 1371-1395, https://doi.org/10.2307/1913103

Klein, P. G., Saidenberg, M. R. (1998). Diversification, Organisation, and Efficiency: Evidence form Bank Holding Companies, https://doi.org/10.2139/ssrn.98653 [Retrieved 2017-11-9] Available at: http://papers.ssrn.com/sol3/papers.cfm?abstract_id=98653

Köhler, M. (2012). Which Banks are More Risky? The Impact of Loan Growth and Business Model on Bank Risk-taking. Deutsche Bundesbank Discussion Paper, 33.

Köhler, M. (2013). Does Non-interest Income Make Banks more Risky? Retail-versus Investmentoriented Banks. Deutsche Bundesbank. Review of Financial Economics No. 23, https://doi.org/10.2139/ssrn.2261120 
Lepetit, L., Nys, E., Rous, P., Tarazi, A. (2005). Product Diversification in the European Banking Industry: Risk and Loan Pricing Implications, https://doi.org/10.2139/ssrn.873490 [Retrieved 2018-06-01] Available at: http://ssrn.com/abstract $=873490$

Lepetit, L., Nys, E., Rous, P., Tarazi, A. (2008). The Expansion of Services in European Banking: Implications for Loan Pricing and Interest Margins. Journal of Banking and Finance, 32(11), 2325-2335, https://doi.org/10.1016/j.jbankfin.2007.09.025

Moshirian, F., Sahgal, S., Zhang, B. (2011). Non-interest Income and Systematic Risk: The Role of Concentration. [Retrieved 2018-5-31] Available at: https://www.newyorkfed.org/ medialibrary/media/research/conference/2011/global_sys_risk/Non-interest_income_ and_systemic_risk.pdf

Nickell, S. (1981). Biases in Dynamic Models with Fixed Effects. Econometrica, 49(6), 14171426, https://doi.org/10.2307/1911408

Odesanmi, S., Wolfe, S. (2007). Revenue Diversification and Insolvency Risk: Evidence from Banks in Emerging Economies. [Retrieved 2017-11-9] Available at: http://www.cass.city.ac.uk/_ data/assets/pdf_file/0007/76921/Odesanmi-97-FINAL.pdf

Roodman, D. (2006). How to do xtabond2: An Introduction to "Difference" and "System" GMM in Stata. Centre for Global Development. Working Paper No. 103, https://doi. org/10.2139/ssrn.982943

Sanya, S., Wolfe, S. (2011). Can Banks in Emerging Economies Benefit from Revenue Diversification? Journal of Financial Services Research, 40(1-2), 79-101, https://doi. org/10.1007/s10693-010-0098-Z

Smith, R., Staikouras, C., Wood, G. (2003). Non-interest Income and Total Income Stability. Bank of England. Working Paper No. 198, https://doi.org/10.2139/ssrn.530687

Stiroh, K. J. (2002). Diversification in Banking Is Noninterest Income the Answer? Journal of Money, Credit, and Banking, 36(5), 853-882, https://doi.org/10.1353/mcb.2004.0076

Stiroh, K. J. (2004). Do Community Banks Benefit from Diversification? Journal of Financial Services Research, 25(2-3), 135-160, https://doi.org/10.1023/b:fina.0000020657.59334.76

Stiroh, K. J., Rumble, A. (2006). The Dark Side of Diversification: The Case of US Financial Holding Companies. Journal of Banking and Finance, 30(8), 2131-2161, https://doi.org/10.1016/j.jbankfin.2005.04.030

Vozková, K., Teplý, P. (2018). Determinants of Banking Fee Income in the EU Banking Industry Does Market Concentration Matter? Prague Economic Papers, 27(1), 3-20, https://doi.org/10.18267/j.pep.645

Windmeijer, F. (2005). A Finite Sample Correction for the Variance of Linear Efficient Two-step GMM Estimators. Journal of Econometrics, 126(1), 25-51, https://doi.org/10.1016/j. jeconom.2004.02.005

Wooldridge, J. M. (2002). Econometric Analysis of Cross Section and Panel Data. Cambridge: MIT Press. ISBN 9780262232586. 